\title{
Needs of Training of Secondary School Teachers on the Framework of the National English Program of Basic Education*
}

\author{
Jorge Mejía Bricaire, Edgar Oliver Cardoso Espinosa, María Trinidad Cerecedo Mercado, \\ Fernando Briseño Hurtado, Joel García Mendoza \\ Sección de Estudios de Posgrado e Investigación Unidad Santo Tomás, Instituto Politécnico Nacional, Mexico \\ City, Mexico \\ Email: jorge28850@otmail.com, eoce@hotmail.com, tricermer@yahoo.com, brisi fer24@yahoo.com.mx, \\ jogmepoem118@yahoo.com.mx
}

Received 23 April 2014; revised 17 May 2014; accepted 7 June 2014

Copyright (C) 2014 by authors and Scientific Research Publishing Inc.

This work is licensed under the Creative Commons Attribution International License (CC BY).

http://creativecommons.org/licenses/by/4.0/

(c) (i) Open Access

\section{Abstract}

This paper discusses the high school teachers' needs of training in the framework of the National English Program in Basic Education (NEPBE). This study aimed to evaluate perceptions of English teachers, in order to describe the social context-culture in the framework of the implementation of the programme. The methodology used was a non-experimental study of transverse type and evaluative character. The sample consisted of 35 professors who carried out the pilot study of the NEPBE in secondary general in the State of Mexico. The instruments used were a questionnaire and an evaluation scale of Likert-type whose application was done in December 2012. Among the main conclusions obtained, it was found that teachers need to identify the subject curriculum standards, they need to own an educational update in the creation of conducive learning environments for English language teaching, and also it was perceived with difficulties in students learning of English as a second language due to the lack of materials and infrastructure.

\section{Keywords}

Teacher Training, Secondary Education, English Language, Curriculum

\section{Introduction}

Nowadays the international context, contemporary trends and international policies, prospective to allow out

\footnotetext{
*Outcome of Master Educational Administration thesis final proposal supervised for Sección de Estudios de Posgrado e Investigación Unidad Santo Tomas del Instituto Politécnico Nacional, Mexico.

How to cite this paper: Bricaire, J. M., Espinosa, E. O. C., Mercado, M. T. C., Hurtado, F. B., \& Mendoza, J. G. (2014). Needs of Training of Secondary School Teachers on the Framework of the National English Program of Basic Education. Creative Education, 5, 969-975. http://dx.doi.org/10.4236/ce.2014.511111
} 
foreign languages teaching at an early age, which are issued or endorsed by important agencies, such as UNESCO (2003) and the OECD (2008), have encouraged that a large number of countries are promoted the incorporation of English teaching with a properly articulated programs in order to assist in the continuous learning of the language (Ramírez, Pamplón, \& Cota, 2012: p. 1). Then, Ramírez et al. (2012) cite to Tocalli-Beller (2007) and Vera (2008) to emphasize that specifically, in Latin America this motion gained higher force at the end of the 90's in countries like Argentina, Chile and Colombia.

In this way, this research focused on secondary school level in order to examine the conditions which teachers develop English teaching within the framework of the National English Program of Basic Education NEPBE and thus, review the needs of high school teachers training in the implementation of the mentioned program. Nevertheless, it was also very important to identify the theoretical foundation, regulations and the evaluation of the programme, as well as a social and cultural context description so as to know teachers' perceptions, significant factors in its development and the objectives accomplishment.

Other similar investigations have focused on the problematic of English Language Teaching as a Foreign Language (ELTFL) in different levels of Mexican public basic education and teachers needs of training, current studies refers to the main problems related to English teaching in primary schools of Mexico are multiple and complex: first, the national programs (knowledge, acceptance levels, consistency between discourse and practice, coverage, financing, status, location of the program, and monitoring); the plans of studies (existence, assigned hours, status, publishers roles); professors (characteristics, training and working conditions); teaching practices and methodologies of teaching and assessment, and educational resources (Ramírez et al., 2012: p. 10).

According to Perez (1990: p. 8) teachers demand more training in the role tutor and especially at primary and secondary levels; Acquisition of strategies and teaching performance techniques: observation, interviews, work habits; In learning to design, develop educational projects and schedules contextualized and well-coordinated; Learning to handle well at the right time and new technologies applied to teaching and learning; Acquisition of classroom research strategies; Learning new research topics and management of qualitative and quantitative methods.

Also Vera (2008: p. 15) asserts that new paradigms in education require better prepared English teachers to take on the great challenges imposed by the current educational processes and globalization trends. Today, teachers are required to be able to take major decisions before the diagnosis, design, implementation and evaluation of the curriculum of English Learner and respond to a greater range of skills.

\section{Background of English Teaching Programs in Mexico}

This brief analysis begins with the 1982 English teaching program, it is considered that before the implementation of this curriculum there was not a defined program, with its own objectives, approach and methodology. Its main objective was the formal knowledge of the language, also established that students should be able to read literature into the studied language (target language), then, written language was considered superior to the spoken one. In order to achieve this objective, students should learn and memorize grammar rules and vocabulary in the target language, in order to translate literary texts.

So then, English study programme emerged inside the framework of the National Agreement for Basic Education Modernization of (NABEM or ANMEB by its Spanish acronym) in 1993 which was supported on the basis of the Communicative approach (Communicative Language Teaching), which it had as a main objective develop the communicative competence, this element understood as the ability to know "what, who and how to say it in an appropriate manner, in any given situation," it moved the attention of formal knowledge of the language to participation in communicative situations, consequently communication was its primary purpose (SEP, 2007).

In this sense, communicative-functional approach of second language (L2) and foreign language (LE) teaching starts to be implemented in 1971 by the Council of Europe in order to promote University students mobility in those countries. The Public Education Secretariat (PES or SEP by its Spanish acronym) (2006) mentions to Wilkins (1976) who distinguished synthetic approaches (in which the students' synthesize linguistic aspects listed in programs or textbooks) and analytical approaches (in which students discuss functionality of the presented input).

The synthetic approach involves segmented teaching and separate the elements of a foreign language (grammar, phonology and functions) and it considered that second acquisition is a process of gradual accumulation of those parts that are integrated at the time of using to communicate. The analytical approach organizes the aspects of language teaching taking into account the purposes for which students are learning such language and 
communicative situations in which they will use it (SEP, 2007).

So, communicative-functional approach aimed at foreign language teaching as communication and did not for communication, it separated formal aspects learning of language as system and it focused only on their functional usage examples. Both approaches emphasizes on knowledge and skills that students should acquire as a result of the teaching and learning processes.

Then, at the beginning of the $80 \mathrm{~s}$, around the world and especially in Europe emerged programs oriented to the process (process-oriented syllabi); According to Nunan (1988), this type of program emphasizes learning experiences that facilitate the acquisition of a language. Task-based approach is an option that allows the teacher to implement a process-oriented program.

The approach based on tasks within the framework of the communicative approach uses a program oriented to the process to overcome the problems that product-oriented programs elicited to teaching of second languages and foreign languages, especially in exolingual contexts (where the students do not have the possibility of being in direct contact with the language learning).

Then, in 2006 emerged a new English program teaching, this comprehensive change was called "Reforma Integral a la Educación Secundaria” (RIES) its approach was taken from the communicative task-based approach which is implemented through projects ("Project-Work"). These projects are developed from a problematic situation in order to be solved by the students guided by the teacher and considering the particular characteristics of each group, it had as a main purpose that students participated in social practices of the language and develop their own communication anywhere.

In this order of ideas, on the framework of regulations that establishes the third constitutional article, The National Development Plan 2007-2012 and the objectives set out in the Sectorial Programme of Education 20072012 SPE, (PROSEDU by its Spanish Acronym), resulted in a comprehensive reform in 2009 called "Reforma Integral a la Educación Básica” (RIEB) in which was presented a new general curriculum.

The SEP recognized the need to incorporate English subject to that new curriculum, for this purpose and in order to implement various actions that enable possible the articulation of English teaching, launched the National English Program in Basic Education (NEPBE), which is derived the curriculum for three levels of basic education, such program has been molded from the alignment and the approval from national and international standards (SEP, 2009). In this way the program is instituted as a new paradigm into Mexican English Teaching.

Consequently for NEPBE, the main purpose of the teaching of English in basic education is that students obtain the knowledge required to participate in language social practices in oral and written language, with native and non-native speakers of English this means by specific competences (SEP, 2009).

This program is divided into four stages or cycles, each one with its own purpose, it is shown in Figure 1.

The particular purpose of the teaching of English in cycle 4 of basic education (1st, $2^{\circ}$ and $3^{\circ}$ of secondary) is that students consolidate their dominance of English in basic communicative situations and develop own specific skill in varied communicative situations in which students, in general, can produce oral and written texts, on various topics, this within the framework of the implementation of the programme (SEP, 2009).

In this regard, the main characteristics of the curriculum for the learning of English in Mexico are presented in Table 1.

Consequently, information presented shows that English programs have changed and therefore the needs of English teachers training also, because English teachers have to develop their teaching task against a new paradigm, or new model, they were ready to work with other kind or programs, said this, according to Ramírez (2012) perspective, the problems associated with these programs changes, include those related to the knowledge of the program, the attitudes and levels of acceptance, the levels of consistency between discourse and practices, coverage, financing, infrastructure, bonding with school principals as well as the follow-up programs; situations that open a review of needs created for teachers from such challenges.

\section{Methodology}

This is a non-experimental, descriptive and evaluative research because it focuses to observe situations and phenomena as given in their own contexts, later to analyze in order to identify English teachers perceptions about NERPBE in order to issue the corresponding value judgments.

In addition, the type of research was cross-sectional, because data were collected in a single moment in time (December 2012) and its main purpose was to describe the variables with their interrelations in a specific time (Hernández, Fernández, \& Baptista, 2010). 


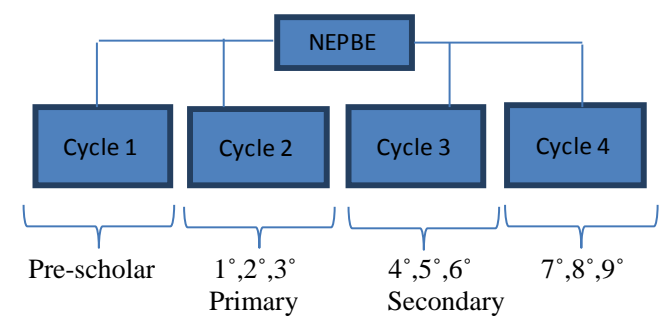

Figure 1. National English program cycles of learning. Source: Own elaboration based on programs of study (SEP, 2007).

Table 1. Historical evolution of the English language programs in Mexico.

\begin{tabular}{|c|c|c|}
\hline Program of studies & Methodological approach & Specific purpose \\
\hline $\begin{array}{l}\text { Study Program of English Teaching of, } \\
\text { 1982, SEP. }\end{array}$ & $\begin{array}{l}\text { Grammar-translation } \\
\text { Method }\end{array}$ & $\begin{array}{l}\text { Student is able to read literature in the target language } \\
\text { because the literary language is considered superior to the } \\
\text { spoken. To achieve this goal, students must know and } \\
\text { memorize grammar rules and vocabulary in the target } \\
\text { language, in order to translate literary texts. }\end{array}$ \\
\hline $\begin{array}{l}\text { Study Program of English Teaching, } \\
\text { 1993. SEP-ANMEB }\end{array}$ & $\begin{array}{l}\text { Communicative Language } \\
\text { Teaching }\end{array}$ & $\begin{array}{l}\text { It aims to develop the communicative competence, } \\
\text { understood as the capacity of knowing "what, who and how } \\
\text { to say it in an appropriate way, in any given situation," shifts } \\
\text { the attention of formal knowledge of the language to } \\
\text { participation in communicative situations i.e., } \\
\text { communication is its primary purpose. }\end{array}$ \\
\hline $\begin{array}{l}\text { English Teaching as a Foraing Language } \\
\text { program from RIES 2006, SEP. }\end{array}$ & $\begin{array}{l}\text { Content-based, Task-based } \\
\text { Approaches }\end{array}$ & $\begin{array}{l}\text { Students participate in social practices of the language and } \\
\text { develop communication in any field. }\end{array}$ \\
\hline NEPBE, 2011. SEP (2011) & $\begin{array}{l}\text { Learning through projects } \\
\text { (Content-based, Task-based } \\
\text { Approaches) }\end{array}$ & $\begin{array}{l}\text { The purpose English Teaching in cycle } 4 \text { of basic education } \\
\text { (1st, } 2^{\circ} \text { and } 3^{\circ} \text { of secondary) is students consolidate their } \\
\text { dominance of English in basic communication situations } \\
\text { and develop specific competences, of practical social } \\
\text { language, into various communicative situations in which } \\
\text { they understand and produce, in general, oral and written } \\
\text { texts about many topics. }\end{array}$ \\
\hline
\end{tabular}

Note: Source: Own elaboration based on programs of study (SEP, 2007).

\subsection{Instrument}

The applied instrument was a questionnaire, which was consisted of the following dimensions based on the NEPBE elements: (1) General data; (2) regulatory framework; (3) purposes; (4) basis and teaching approach; 6) curriculum standards; (7) the learning organization; (8) assessment; 9) teaching materials; 10) teaching guidelines; (11) English teaching features.

It was used a Likertrating scale which corresponds to a method of summed ratings, this method has the advantage that does not use judges and involves the development of a large number of statements, which are applied to a representative sample of the universe of study (Rosado, 2003: p. 174), especifically the opinions of teachers within the framework of the implementation of the NEPBE.

\subsection{Sample and Context}

The study sample was not random or directed type, for this reserch 35 teachers, from the general secondary schoolar zone S-096 in the State of Mexico, participated in the aplication of such instrument. It should be noted that this kind of sample, the choice of the elements, do not dependent of probabillity, it depends of the own researcher causes (Hernández et al., 2010).

\section{Results}

In this way, there are some important results that give place to the analysis of training needs of secondary-level English teachers. 
It was found that Teachers Pupiliage who participated in the study round $85 \%$ and they have an undergraduate studies, $3 \%$ a kind of specialty and $12 \%$ have postgraduate studies in this case a master degree. In addition, the age ranges round 22 to 24 years and the rest of the sample round 25 to 54 years old, these ranges indicate that there is a relatively young staff which works with the NEPBE.

Meanwhile, $66 \%$ of participants affirmed they have a very well opinion about the program, other $25 \%$ claims to have a bad opinion of the NEPBE and only 3 teachers $9 \%$ say to have a regular view of the program, this indicates that most of teachers have a good perception of the program.

$60 \%$ of teachers perceived that the scope of the general purpose are spacious and well-planted, while $26 \%$ of teachers affirmed that they are little broad and only $14 \%$ said that they are limited, which implies that only a minority of the respondents perceived that the scope of the general purpose is limited. Another important result was $60 \%$ of teachers said that contents of teaching and achievements organization develops comprehension, specifically the oral and written expression while the other $40 \%$ felt in general that the program does not develop these skills.

It was founded that $63 \%$ of the teachers say that organization of the contents of teaching and achievements develop relevant attitudes to language and communication and they are possible with the program, while in general the other $37 \%$ expressed that it is not possible to carry out to implement these attitudes.

In relation to the assessment, $46 \%$ said that such item is a central element of NEPBE, while $37 \%$ of teachers indicated that it is a somewhat important element, finally only $17 \%$ of the surveyed teachers felt that evaluation is not a central element of the curriculum.

In the field of materials used as teaching resources, the results indicated that $60 \%$ of the surveyed teachers often used physicists materials (cardboards, Visual cards), while 25\% used virtual materials (web pages, online exercises) and just $5 \%$ of teachers claimed for other kind of hearing materials (tracks, songs and chats).

The using of Information Communication Technologies (ICT) as an English teaching resource 37\% of surveyed teachers said that they are actually necessary for teaching sessions in English, while $25 \%$ considered that they are not necessary, however the 38\% perceived that ICT are sometimes necessary for the teaching of English sessions. Another interesting result is the perception of teachers on the essential features that must have an English teacher, it was found that $34 \%$ of teachers established that the most important essential knowledge is the domain of contents, followed by a $29 \%$ who considered that teaching is more important, and with a lower percentage $23 \%$, felt that the teacher should have one or more certification of English language and English language teaching and as a feature with less range $11 \%$ claimed for knowledge of adolescents.

While, on second part, and attached on the scale of evaluation described in the methodology, it was founded that $49 \%$ of teachers were agreed completely, and they considered appropriate the regulatory framework of the programme; the $3 \%$ is agreed, $17 \%$ and $6 \%$ was found in disagreement, because they considered inappropriate the normative framework of this programme, $26 \%$ of teachers were in a neutral position.

In the expected levels of achievement by cycle and degree and feasibility based on the characteristics of the infrastructure of schools, it was found that $54.3 \%$ of teachers are in an attitude of indifference; $11.4 \%$ were found totally agree, in counterpart to $8.571 \%$ who were totally disagree.

It was observed that $41 \%$ of teachers agreed and $17 \%$ strongly agreed with the feasibility of the proposed goals established for the purpose of English teaching in Cycle 4, corresponding to secondary; this based on the characteristics of students and school infrastructure where they worked, while $6 \%$ and $14 \%$ were Totally disagreed and disagreed respectively, $42 \%$ of secondary teachers, agreed, and $14 \%$ strongly agreed that it is possible to implement guidelines or interaction modes, in addition to production or interpretation of oral and written texts in the classroom under the PNIEB.

In addition to this, $31 \%$ felt totally agree and $29 \%$ thought, that it is possible that social learning environments laid out in the program contribute to preserving the social functions of specific skills with language and the possibility that the student assigned to them a personal sense and actively participate in acts of reading, writing and oral exchanges; $26 \%$ reported against adopting a neutral position on this question , and finally a $6 \%$ and $9 \%$ perceived disagree and strongly disagree respectively.

\section{Conclusion}

All main conclusions obtained in this research are featured as follows:

Thus, from results presented is analyzed that teaching staff has a significant profile of specialization in the field 
of language, however graduate teachers stances it is still low, so it is necessary for teachers to adopt a vertical professionalization language teaching.

Meanwhile teachers should know the Organization of the contents of teaching and achievements to develop comprehension, specifically the oral and written expression, also found that teachers should know the Organization of the teaching contents which are oriented to develop relevant attitudes towards the language and communication within the framework of the implementation of the programme in the classroom, directly with the students.

In relation to the assessment, teachers should know the regulations, as well as the establishment of criteria and indicators to carry out rigorous evaluation as it is contemplates it the English curricula.

In the field of materials as resources for education, the results indicated that the majority of teachers still used physicists materials (cardboards, Visual cards), while a minority uses virtual materials (web pages, online exercises) and only a small part used materials (tracks, songs) hearing and listenings (conversations), which indicates that teachers need to use and learn about suitable materials for the development of specific competencies required program, also teachers need to have a serious technological infrastructure at each school in order to use ICT as a resource for English teaching.

The perception of teachers on their own essential characteristics is that an English teacher must have was established that is the domain of contents, followed by the didactics, thus certifications extended by evaluation organizations of language and as a characteristic with less range the knowledge of adolescents.

Finally, the NEPBE, is an excellent decision in the field of curriculum change, however on the evaluated perceptions it was found that the program is faulty in its operation, the purposes and the teaching curriculum standards are good, nevertheless at this time are considered difficult to achieve, because exists difficulty in the creation of learning environments for English teaching and learning as a second language due to the lack of materials.

These results lead to say that English teacher training needs must be oriented to the domain of the contents of the language, the certification of language teachers, in the domain of pedagogy and forms of education, also they must have a real knowledge of adolescents, so it is necessary that the teachers possess a pedagogical update in the creation of English language learning and teaching environments.

\section{Discussion}

Being consistent with these findings, it is necessary to orient the conclusions reached in this paper at new forms of work by educational actors (Government, Principals, School Managers, Teachers, students, parents), and taking a look into these results it could be profitable to say that there are several advantages that NEPBE offers to Mexican English language students, this new syllabus create a real learning environment in contrast to 2006 English language teaching program, NEPBE develops communicative strategic competences and it represents a real educational policy of English teaching made by the federal administration, nevertheless if education authorities wants to make more efficient such program, government must pay attention (as an emergent and urgent task) on formation teachers demands exposed in this paper. The attention to English teachers particularities, and also all their individual process of knowledge construction and their teaching competences will guarantee better english language sessions into each classroom and therefore better prepared students, they will be opened to knowledge of other cultures.

Of course, it is necesary that government equip English classrooms of basic education in other words it must be improved all infrastructure in each school, with these actions arepromoted the digital inclusion and access to students' knowledge and also those with special needs. Finally, these virtual environments will constitute a huge corpora to attend english teaching and learning educational backwardness.

\section{Further Studies}

It is suggested to continue this exploratory study using a longitudinal study, much more detailed about students, managers and family partners English learning on the framework of NEPBE.

\section{Acknowledgements}

The writers wish to acknowledge to teachers whose participate in this investigation and the Postgraduate Studies and Research Department of the National Polytechnical Institute (IPN, for its acronym in Spanish) for their continuous support for this study and for sharing the same passionate commitment to promote best practices in 
teaching through action research.

\section{References}

Hernández, R., Fernández, C., \& Baptista, P. (2010). Metodología de la investigación. México City: McGraw Hill.

Nunan, D. (1988) Syllabus Design. Oxford: Oxford University Press.

Organización para la Cooperación y el Desarrollo Económicos (OCDE) (2008). Globalisation and Linguistic Competencies. Responding to Diversity in Language Environments. http://www.oecd.org/dataoecd/55/15/41363216.pdf

Perez, M. (1990). Quénecesidades de formaciónperciben los profesores (p. 8). Madrid: Universidad Autónoma de Madrid.

Ramírez, J. L., Pamplón, E. N., \& Cota, S. (2012). Problemática de la enseñanzadelinglés en lasprimariaspúblicas de México. Revista Ibero-americana de Educación, 2, 12p. http://www.rieoei.org/deloslectores/5020Ramirez.pdf

Rosado, M. (2003). Metodología de la investigación y la evaluación (p. 253). México City: Trillas.

SEP (2007). Programa Sectorial de Educación. México City: SEP.

SEP (2009). ProgramaNacional de inglés en la EducaciónBásica. México City: SEP.

SEP (2011). Plan de estudios. México City: SEP.

United Nations Educational, Scientific and Cultural Organization (UNESCO) (2003). Education in a Multilingual World, París.

Vera, F. (2008). Estado del Arte de la Profesión de Profesor de Inglés: “Quéocurre en Chile” (p. 15). Chile. http://www.utemvirtual.cl/nodoeducativo/wp-content/uploads/2009/03/art_fvera.pdf 
Scientific Research Publishing (SCIRP) is one of the largest Open Access journal publishers. It is currently publishing more than 200 open access, online, peer-reviewed journals covering a wide range of academic disciplines. SCIRP serves the worldwide academic communities and contributes to the progress and application of science with its publication.

Other selected journals from SCIRP are listed as below. Submit your manuscript to us via either submit@scirp.org or Online Submission Portal.
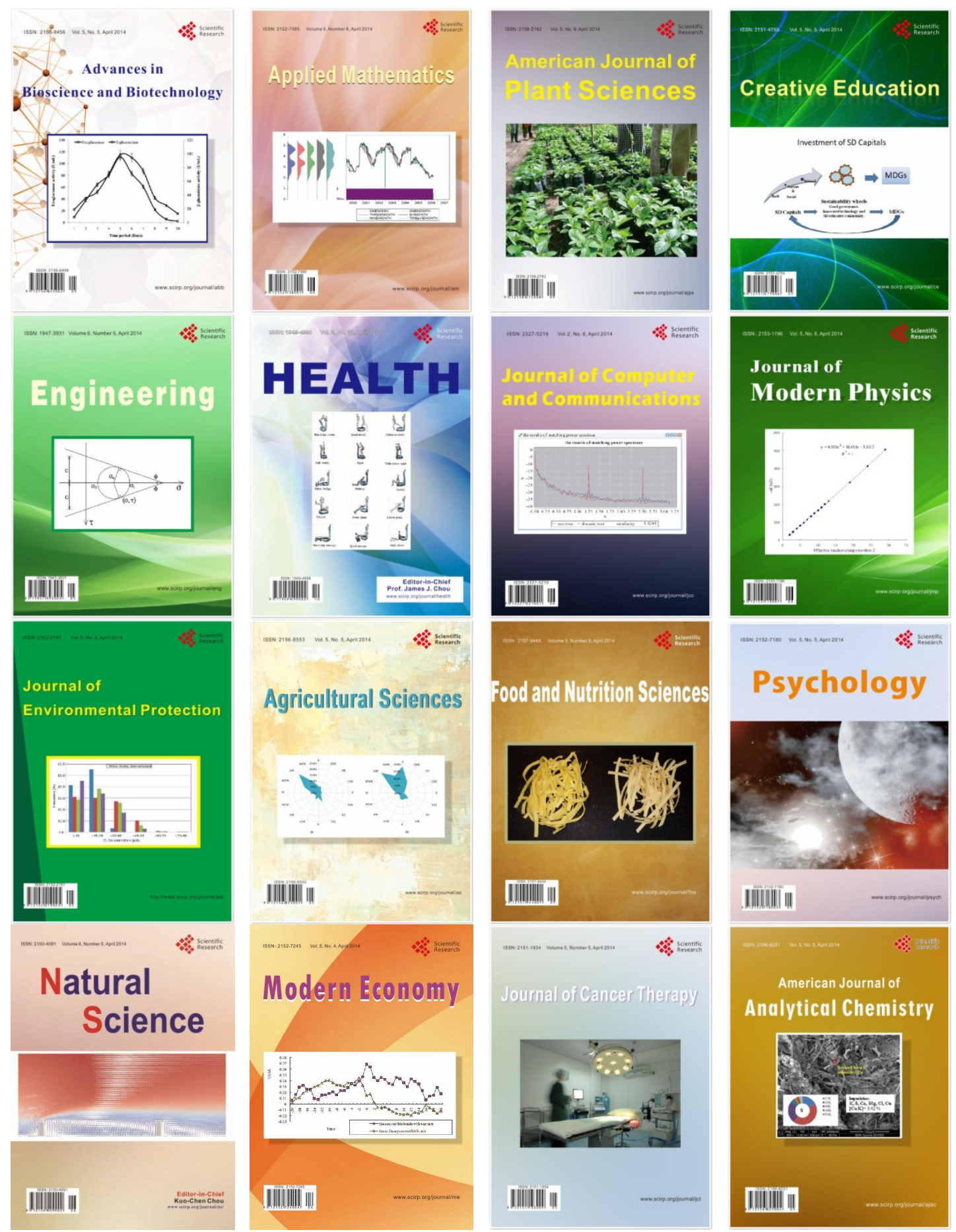